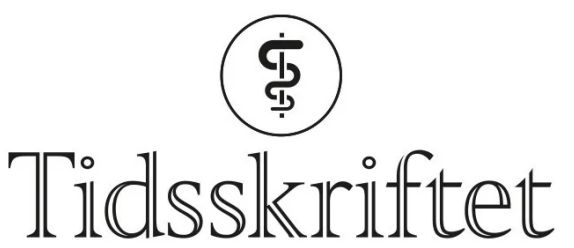

DEN NORSKE LEGEFORENING

\title{
Kan desentralisert legeutdanning bli for fragmentert?
}

DEBATT

\section{ANNA MIDELFART}

anna.midelfart@medisin.ntnu.no

Anna Midelfart er professor emeritus i øyesykdommer ved NTNU.

Forfatteren har fylt ut ICMJE-skjemaet og oppgir ingen interessekonflikter.

\section{KÅRE REITEN}

Kåre Reiten er spesialist i allmennmedisin og fastlege ved Holmen legesenter i Stavanger. Forfatteren har fylt ut ICMJE-skjemaet og oppgir ingen interessekonflikter.

\section{Det er bred enighet om at flere leger bør utdannes i Norge. Dette bør skje ved å opprette et nytt fakultet, og ikke gjennom fragmentering av fag- og studiemiljø.}

Det er politisk og faglig enighet om at vi må utdanne flere leger i Norge, men hvordan dette skal gjøres, er fremdeles uklart. I 2019 anbefalte Grimstadutvalget en opptrapping med 440 studieplasser for å kunne dekke $80 \%$ av landets behov for leger (1). Som en begynnelse ble de fire fakultetene i Oslo, Bergen, Trondheim og Troms $ø$ nylig tildelt 8 o nye studieplasser i medisin (2). På forhånd ble det lagt vekt på at utdanningen også skulle desentraliseres. Tre modeller er blitt etablert: Bodøpakken, Finnmarksmodellen og NTNU $\operatorname{link}(3)$.

Argumentene bak økt desentralisering av medisinstudiene er ønsket om å styrke utdanningen gjennom praksisnærhet på små enheter, avlaste universitetsklinikkene og samtidig øke rekrutteringen til distriktene (3,4.). For studentene innebærer denne utdanningsmodellen at grupper med 12-16 studenter utplasseres i to år midt i eller på slutten av studietiden ved sykehusene i Bod $\varnothing$ (UiT - Norges arktiske universitet), Levanger/Namsos (NTNU) eller Hammerfest (UiT - Norges arktiske universitet). Studentene vil også ha praksis i kommunehelsetjenesten (3).

\section{Er desentralisering løsningen?}

Vi har forståelse for de mangeårige problemene med å rekruttere leger til deler av distriktsNorge. Men spørsmålet er om den desentraliserte modellen for legeutdanning skal være et virkemiddel for å løse alvorlige samfunnsmedisinske problemer som dagens helsevesen 
sliter med? Blir studentenes interesser nedprioritert i strebenen etter å løse legemangel og andre organisatoriske forhold? Vil man i tilstrekkelig grad klare å legge vekt på viktige pedagogiske prinsipper, studiekvalitet og utdanningsperspektiv? Og, ikke minst: Vil man kunne ivareta intensjonen med en helhetlig nasjonal utdanning?

«Blir studentenes interesser nedprioritert $i$ strebenen etter å løse legemangel og andre organisatoriske forhold?»

Modellen med en desentralisert legeutdanning ble nylig presentert i Tidsskriftet av Ingrid Petrikke Olsen og medforfattere, som konkluderer med at det er gode grunner til å hilse denne velkommen (3). Artikkelen oppsummerer mange forventninger til dette prosjektet, men vi savner en grundig drøfting av utfordringene og mulige svakheter. Vi savner også en sammenligning mellom desentraliserte utdanningsmodeller og et nytt og samlet utdanningsløp i Stavanger (5).

\section{Medisin som akademisk utdanning}

Årene som universitetsstudent gir en enestående mulighet til å være en del av et kulturelt fellesskap med andre studenter på tvers av fagmiljøer. Mange får også innblikk i forskningsaktiviteter både ved universitetet og universitetssykehuset, som er en verdifull erfaring å bygge videre på. Dette trenger Norge.

Utplasseringsperioder i studietiden med varighet opptil et semester husker mange med glede, og det er en viktig del av medisinstudiet.

\section{"Kan utdanningskvaliteten $i$ en desentralisert modell bli satt under for stort press av fastlegekrisen?»}

Vi er overbevist om at studentene også i dag møter både engasjerte, dyktige, kunnskapsrike og hjelpsomme kolleger som undervisere og veiledere på mindre sykehus. Men flere års utplassering på mindre sykehus - også for den akademiske delen av studiet - er noe helt annet. Det reiser flere spørsmål. Først og fremst: Vil de utplasserte studentene miste noe av samhørigheten med det øvrige akademiske miljøet og «sitt» kull ved universitetet? Hva betyr det for dem, og kan det også ha yrkesmessige konsekvenser senere? Kan det være vanskeligere for disse studentene å få legestillinger sentralt hvis de ønsker det? Hvordan skal utvelgelsen foregå, hvilke studenter skal ha et desentralisert opplegg og hvilke skal ha et sentralt? Kan utdanningskvaliteten i en desentralisert modell bli satt under for stort press av fastlegekrisen og den til tider vanskelige bemanningssituasjonen ved sykehus i distrikts-Norge? Finnes det bedre virkemidler for å stimulere rekrutteringen av leger til distriktene enn en desentralisert utdanningsmodell?

Kan det tenkes at begeistringen for desentralisert utdanning også har en sammenheng med manglende undervisningskapasitet ved de etablerte medisinske fakultetene, nå som flere leger skal og bør utdannes i Norge? Blir dette også en strategi for å opprettholde dagens status quo fremfor å hilse velkommen og erkjenne behovet for et nytt medisinsk fakultet i Stavanger (5)? Vi bare spør!

\section{LITTERATUR}

1. Grimstadutvalget. Studieplasser i medisin i Norge. Behov, modeller og muligheter. Oslo: Kunnskapsdepartementet, 2019.

https://www.regjeringen.no/contentassets/9b5b81d102384507b8515of2eof1bo89/117459oo_rapport_utr edning_fra_grimstadutvalget.pdf Lest 12.10.2021. 
2. Regjeringen. Utdanningsløftet 2020: Her kommer de nye studieplassene.

https://www.regjeringen.no/no/aktuelt/utdanningsloftet-202o-her-kommer-de-nye-

studieplassene/id2703859/ Lest 6.10.2021.

3. Olsen IP, Lilebo B, Øfstad EH et al. Tid for å utdanne flere leger desentralt. Tidsskr Nor Legeforen 2021; 141: 1042-3. [PubMed][CrossRef]

4. Grimstad H. Skal vi utdanne legene der de trenges? Tidsskr Nor Legeforen 2017; 137: 14-5. [PubMed] [CrossRef]

5. Munkvik M, Alsnes IV, Ørn S. Ny giv for norsk legeutdanning. Tidsskr Nor Legeforen 2021; 141: 824-5. [PubMed][CrossRef]

Publisert: 8. november 2021. Tidsskr Nor Legeforen. DOI:10.4045/tidsskr.21.0614

Mottatt 27.8.2021, første revisjon innsendt 30.9.2021, godkjent 12.10.2021.

(C) Tidsskrift for Den norske legeforening 2023. Lastet ned fra tidsskriftet.no 26. april 2023. 